\title{
The effect of starter combination and types of milk against physicochemical characteristics of cow milk yoghurt
}

\author{
Erina Septianti*, Wanti Dewayani and Riswita Syamsuri
}

Assessment Institute for Agricultural Technology in South Sulawesi Perintis Kemerdekaan Km. 17.5 Makassar, South Sulawesi, Indonesia

\begin{abstract}
Yoghurt was produced through the fermentation of bacteria Lactobacillus bulgaricus and Streptococcus thermophillus. In making yoghurt, various kinds of milk can be used such as: fresh milk, skim milk and full cream milk. The purpose of the study is to provide yoghurt in accordance with the right application of milk and yoghurt starter. The findings of research provide scientific information that useful for the technology development in the field of cow's milk processing industry. The study began with making starter, processing milk to be yoghurt and storing them in cold temperatures for four weeks. The study used a factorial Completely Randomized Design with three replications. The first factor is the number of starter/Lactic Acid Bacteria (e1 = Lactobacillus bulgaricus and Streptococcus thermophillus; e2 = combination of Lactobacillus bulgaricus, Streptococcus thermophillus, Bifidobacterium longum and Lactobacillus casei). The another factor is types of milk ( $s 1=$ fresh milk and $s 2=$ skim milk). The parameter was discussed are physicochemical analysis including $\mathrm{pH}$, protein, fat and lactose content. The results was showed the types of milk and the amount of starter used had a significant effect on fat content, protein content and lactose of the yoghurt produced did not match the $\mathrm{pH}$ value of yoghurt during storage at 4 weeks. The $\mathrm{pH}$ value obtained from fresh milk ingredients with a combination of 4 starters, a good level of yoghurt protein is produced from fresh milk ingredients with a combination of 2 starters, good fat content obtained from skim milk ingredients with a combination of 2 starters and fresh milk with a combination of 4 starters, while good lactose content in a combination of 2 starters both in fresh milk and skim milk.
\end{abstract}

\section{Article History}

Received June 25, 2020

Accepted December 30, 2020

\section{Keyword}

yoghurt, fresh milk, skim milk, lactic acid bacteria.

\section{Introduction}

Milk is a high nutritional value foodstuff because it contain complete nutrients such as: lactose, fat, protein, various vitamins and minerals $(1,2)$. In $100 \mathrm{ml}$ of cow's milk as the basic ingredient of making yoghurt has nutritional composition in the form of: vitamin A 158 IU; vitamin D $2.0 \mathrm{IU}$; vitamin B6 $0.036 \mathrm{mcg}$; calories $69 \mathrm{kcal}$; protein $3.3 \mathrm{~g}$; fat $3.7 \mathrm{~g}$; lactose 4.8 g; calcium $125 \mathrm{mg}$; casein 2.8 grams; iron $0.10 \mathrm{mg}$ and other minerals $0.72 \mathrm{~g}(3,4)$.

Cow milk more easily damaged than other livestock products then handling postharvest milk must be precise and fast. The example of simple milk processing was boiled the milk and serve for drink. In recent years, diversification of dairy products is an effort improve value of dairy products. The one famous product from milk is yoghurt. Yoghurt is one of the simple processed milk products has long been developed around the world $(5,6)$. The process of making yoghurt used various kinds of milk including: cow's milk, goat's milk, 
condensed milk, cream milk and skim milk (7-9). Fresh milk from animal need more attention in their handling and storage $(2,10,11)$. Beside milk from animal, nowadays yoghurt also be made from a mixture of skim milk with vegetable product such as soy milk (12) and coconut milk (13).

Yoghurt is the result of fermentation of certain bacteria such as cheese (14-16). Actually yoghurt is a food derived from milk as the result of curing milk in a form similar to porridge or ice cream with a slightly sour taste (17). In the beginning, yoghurt comes from the Turkish word jugurt means sour milk $(13,18,19)$. Yoghurt has a higher nutritional value than fresh milk which is the basic ingredient in making yoghurt. The fermentation process caused increase in total solid and content of other nutrients in milk also increased. Commonly yoghurt contain more protein (6.30\%), fat (6.73\%), vitamin A (80 SI), lactic acid, citric acid, pyruvic acid, formic acid, uric acid, butyric acid and oricic acid (20-22).

Besides being highly nutritious, yoghurt is also easier to digest in the stomach when compared to cow's milk (23). Yoghurt is a good remedy for stomach and intestinal wounds, cholesterol levels in the blood also reduced by consuming yoghurt. The other benefit is preventing the occurrence of blood vessel blockage (artherosclerosis). Yoghurt is very suitable for consumption by patients with lactate deficiency in the body or lactose intolerance, where the body is unable to convert lactose into glucose and galactose. This disorder results in stomach pain and diarrhoea after consuming milk. By consuming yoghurt, the incident will not occur. Yoghurt has a higher protein content than cow's milk and is low in fat. This is very useful for people increasing healthy in diet $(24,25)$.

The quality of the resulting of fermented product such as yoghurt greatly influenced by several important factors such as: milk quality, storage time, incubation temperature and type of starter used (11,26-29). In general, fermentation of milk into yoghurt is formed by lactose fermentation into lactic acid due to the presence of lactic acid bacteria namely: Streptococcuss alivarius, S. thermophillus, Lactobacillus delbrueckii, L. bulgaricus, L. acidophilus, L. casei and L. bifidus. Bacteria such as L. bulgaricus and S. thermophillus are lactic acid bacteria has ability convert lactose in milk to lactic acid then milk is more easily digested by the stomach (30,31). In similar study, El Bashiti (2010); Glusac et al. (2015) and Rahman et al., (2016) reported that process made of traditional yoghurt in the world wide commonly used starter from S. thermophillus and L. bulgaricus $(18,32,33)$.

Besides being made from fresh milk, yoghurt also be made from skim milk (non fat milk) dissolved in water in a certain ratio depending on the thickness of the desired product (34). Making yoghurt derived from skim milk is very easy and has more benefit. Skim milk contains all nutritional components except fat and some fat-soluble vitamins (35). According to Stanley (2008) reported that skim milk has ability reduce the risk of coronary heart disease because 1 litre of fresh milk contains fat by $132 \mathrm{mg}$, while skim milk only $16 \mathrm{mg}$ (36). Skim milk is also a good source of protein, but has a low energy content because they only contains 55\% of all milk energy. However, the research of Khusmiati et al., (2004) explain that the physical and chemical properties of fatty green tea yoghurt are better than skim green tea (37). In the similar research, Rachman et al. (2018) reported benefit of rosella mixed with yoghurt from cow and goat milk contain many nutrient and improving health (3).

The variety types of milk and starters used in yoghurt processing is the basis for consideration of research on the effect of variations of starter on the quality of yoghurt produced. In the future, finding of research can be recommended in increasing the productivity of yoghurt processing. 


\section{Materials and Methods}

The fresh cow's milk used as an ingredient in making yoghurt comes from the cattle farm Frisian Holstein in Enrekang Regency, South Sulawesi. The study was conducted at the Post Harvest Laboratory of AIAT South Sulawesi in January to December 2016.

\subsection{Research Methods}

\subsubsection{Preparing starter of yoghurt}

$500 \mathrm{ml}$ of fresh milk put into two measuring cups, each containing $250 \mathrm{ml}$, then pasteurize at $60-65^{\circ} \mathrm{C}$ for 30 minutes. Next the measuring cup is removed and the temperature is lowered to $45^{\circ} \mathrm{C}$. After the milk is cold then inoculated using starter bacteria as much as $3 \%$ of the volume of raw materials. Subsequently added with sufficient skim milk and stored in a room temperature of $25-27^{\circ} \mathrm{C}$ for 24 hours.

\subsection{Treatment Stage}

The making of yoghurt used four treatment groups respectively:

Treatment I: $500 \mathrm{ml}$ of pasteurized fresh milk then cooled to $40^{\circ} \mathrm{C}$, added $10 \mathrm{ml}$ of starter combination S. thermophillus and L. bulgaricus.

Treatment II: dilute $25 \mathrm{~g}$ of non-fat milk (skim milk) using $500 \mathrm{ml}$ of water then pasteurized and cooling to a temperature of $40^{\circ} \mathrm{C}$. Added $10 \mathrm{ml}$ of starter combination $\mathrm{S}$. thermophillus and L. bulgaricus

Treatment III: $500 \mathrm{ml}$ of pasteurized fresh milk then cooled to $40^{\circ} \mathrm{C}$, added $20 \mathrm{ml}$ of starter combination Streptococcus thermophillus, Lactobacillus bulgaricus, Bifidobacterium longum and Lactobacillus casei.

Treatment IV: dilute $25 \mathrm{~g}$ of non fat milk (skim milk) using $500 \mathrm{ml}$ of water, pasteurize and cooling to $40^{\circ} \mathrm{C}$, then added $20 \mathrm{ml}$ of starter combination of S. thermophillus, L. bulgaricus, B. longum and L. casei.

All treatments were stirred evenly until mixed then incubated for 8 hours at room temperature. After the incubation is finished, put $63 \mathrm{~g}$ of sugar then stored in a bottle container. Yoghurt has been packaged immediately cooled in the refrigerator avoid continue of fermentation process.

\section{Storage}

The milk in process become yoghurt stored at cold temperatures and observed from the first week to the fourth week with an observation time interval of 7 days.

\subsection{Experimental design}

The research treatment used two starter combinations namely: (e1= combination of $L$. bulgaricus and $\mathrm{S}$. thermophillus; $\mathrm{e} 2$ = combination of L. bulgaricus, $\mathrm{S}$. thermophillus, $\mathrm{B}$. longum and L. casei) with variations in milk (s1 = fresh milk and $s 2=$ skim milk). The study used a Completely Randomized Design in factorial pattern with 3 replications. The yoghurt production then stored until 4 week at cold temperatures $(4 \circ \mathrm{OC})$. During the four-week storage period the $\mathrm{pH}$, crude protein, fat content and lactose content of the yoghurt were measured. The collected data is tabulated, analyzed with ANOVA analysis (Analysis of 
Variance). When the real $\mathrm{F}$ test is continued to the DMRT multiple test (Duncan Multiple Range Test).

\section{Results and Discussion}

\section{1. $p H$}

The $\mathrm{pH}$ measurement is carried out to determine the acidity level of the yoghurt during 4 week storage period. The measurement results showed that the treatment of starter on different types of milk did not have a significant effect on the $\mathrm{pH}$ of the yoghurt produced (Table 1).

\begin{tabular}{lllllll}
\multicolumn{1}{l}{$\begin{array}{l}\text { Table 1. Results of Yoghurt pH During Storage } \\
\text { Treatment Factor }\end{array}$} & Milk Treatment & $\mathrm{pH}$ & & & \\
\cline { 2 - 7 } $\begin{array}{l}\text { of Starter Type } \\
\text { (e) }\end{array}$ & Factor (s) & 0 & 1 & 2 & 3 & 4 \\
\hline e1 (Combination L. bulgaricus & s1 (fresh milk) & $4.03 \mathrm{gh}$ & $5.33 \mathrm{~b}$ & $4.97 \mathrm{~cd}$ & $4.97 \mathrm{~cd}$ & $4.53 \mathrm{f}$ \\
and S. thermophillus) & s2 (skim milk) & $3.83 \mathrm{~h}$ & $4.87 \mathrm{~d}$ & $4.97 \mathrm{~cd}$ & $4.90 \mathrm{~cd}$ & $4.57 \mathrm{ef}$ \\
e2 (Combination L. bulgaricus, & s1 (fresh milk) & $4.17 \mathrm{~g}$ & $4.97 \mathrm{~cd}$ & $5.13 \mathrm{bc}$ & $4.93 \mathrm{~cd}$ & $4.17 \mathrm{~g}$ \\
S. thermophillus, B. longum & s2 (skim milk) & $4.23 \mathrm{~g}$ & $4.77 \mathrm{def}$ & $5.6 \mathrm{a}$ & $4.80 \mathrm{de}$ & $4.53 \mathrm{f}$
\end{tabular}

and L. casei)

The numbers followed by the same letters in the same column are not significantly different in Duncan's multiple range test $\alpha=0.05$

Table 1 was showed the $\mathrm{pH}$ values obtained during storage have increased until 2 week and decreased until 4 week. The highest $\mathrm{pH}$ value obtained in yoghurt from skim milk with a combination 4 starters in the periods 2 week was 5.6. The lowest pH was found in yoghurt from skim milk used combination of 2 starters at the initial observation of 3.83. At the periods 4 week, the $\mathrm{pH}$ produced was not significantly different between the treatment using 2 starters and 4 starters on fresh or skim milk. The resulting $\mathrm{pH}$ value is still within the yoghurt standard $\mathrm{pH}$ limit. The resulting of $\mathrm{pH}$ range is between 4.17 to 4.57 where the highest $\mathrm{pH}$ is obtained from the combination treatment of 2 starters in skim milk. According to Jay et al. (2005) and Kim et al. (2008) the normal pH standard for yoghurt ranges from 3.8 - $4.8(38,39)$. The amount of $\mathrm{pH}$ strongly influenced by temperature, incubation time and the number of starters as ingredients used for fermentation by lactic acid bacteria thus accelerating the decrease in $\mathrm{pH}$. However, Lahtinen et al. (2005) reported that the bacteria possible to be dormant because temperature and environment condition in fermentation process (40).

The increase in the $\mathrm{pH}$ value of yoghurt caused by decreased activity of Lactic Acid Bacteria (LAB) then total acid also decreases. According to Oktavia et al. (2015) and Rukmi et al. (2015) who reported that during storage, acid production decreased with the decrease in BAL activity in breaking down lactose into lactic acid which was marked by the decreasing amount of LAB still alive (41). This causes the $\mathrm{pH}$ of yoghurt to increase. The decrease in the acidity of yoghurt affect the presence of volatile organic compounds/volatile acids which are lost during anaerobic fermentation.

$L A B$ activity will affect the acidity of yoghurt because the metabolite product used is lactic acid. $L A B$ can grow optimally at environmental $\mathrm{pH} 4.0-5.0$ and experience a significant decrease at $\mathrm{pH}<4(38,42)$. The low $\mathrm{pH}$ of bacterial growth media is an important factor inhibit the survival of lactic acid bacteria $(40,43)$. The results of Oktavia et al., $(2015)$ 
showed that storage of black mulberry yoghurt during distribution and marketing caused the increasing acidity of yoghurt (41). In contrast, Suriasih et al., (2014); Wulansari and Kusmayadi (2016) reported that yoghurt from blended cow and goat milk had higher nutrient content and easy digest than their milk $(7,24)$. In another way, cow milk yoghurt adding different fruit increasing their benefit. This is useful information about benefit from fermented food inreasing health of consumers.

\subsection{Fat Content}

The results of the fat content analysis showed the types of milk used and the variation of the starter used has influence on the yoghurt produced (Table 2).

Table 2. Results of Yoghurt Fat Levels During Storage

\begin{tabular}{llll} 
Treatment Factor of Starter Type (e) & $\begin{array}{c}\text { Milk Treatment } \\
\text { Factor (S) }\end{array}$ & $\begin{array}{c}0 \\
\text { week } \\
(\%)\end{array}$ & $\begin{array}{c}4 \\
\text { weeks } \\
(\%)\end{array}$ \\
\hline $\mathrm{e}_{1}$ (Combination L. bulgaricus and S. thermophillus & $\mathrm{s}_{1}$ (fresh milk) & $2.75 \mathrm{a}$ & $1.44 \mathrm{~b}$ \\
& $\mathrm{~s}_{2}$ (skim milk) & $0.13 \mathrm{e}$ & $0.04 \mathrm{f}$ \\
$\mathrm{e}_{2}$ (Combination L. bulgaricus, S. thermophillus, $B$. & $\mathrm{s}_{1}$ (fresh milk) & $0.48 \mathrm{~d}$ & $0.60 \mathrm{c}$ \\
longum and L. casei) & $\mathrm{s}_{2}$ (skim milk) & 0.09 ef & 0.08 ef \\
\hline The numbers followed by the same letters in the same column are not significantly different in Duncan's \\
multiple range test $\alpha=0.05$
\end{tabular}

The result of fat content determine since 1992 in Indonesian National Standard for yoghurt quality with maximum of $3.8 \%$. The results of statistical analysis showed that the types of milk and composition of starter significantly affected the fat content of yoghurt produced. The highest fat content in the 4 week was obtained from the combination treatment of 2 starters in fresh milk by $1.44 \%$ while the lowest fat content by $0.04 \%$ from the combination of 2 starters in skim milk. The fat content of yoghurt depends on the original fat content from milk as their ingredients.

Yoghurt fat content during storage decreased in each treatment except for the combination treatment of 4 starters in fresh milk increased from $0.48 \%$ to $0.60 \%$. In fresh milk yoghurt with a combination of 2 starters the initial fat content of $2.75 \%$ decreased to $1.44 \%$, yoghurt from skim milk with combination of 2 starters initially $0.13 \%$ decreased to $0.04 \%$. While skim yoghurt with a combination of 4 starters from $0.09 \%$ decreased to $0.08 \%$. The fat content of yoghurt using skim milk is lower when compared to fresh milk because skim milk has very lower fat when compared to fresh milk. Based on the results of Sunarlim and Setiyanto research (2001), it showed that yoghurt made from pure milk has a higher fat content, which is around $5.25 \%$, which is statistically significant compared to $2 \%$ fat milk, obtained by yoghurt with $2.23 \%$ fat content and $1.03 \%$ for skim milk (non fat)(44).

A decrease in fat for all yoghurt produced during storage because during fermentation the fat contained in milk turns into simple compounds. Yusmarini et al., (1998) and (Hafsah and Astrina, 2012) stated that during fermentation, fat will be hydrolyzed into simple compounds. Good quality yoghurt contain lower fat content than the basic ingredient in this case is cow's milk $(45,46)$.

\subsection{Protein content}

Protein is useful for increasing the nutritional value and sources of nitrogen that used by BAL for its growth in fermented products. This protein will be used for the formation of 
bacterial cells (47). The results of testing yoghurt protein levels during storage was presented in Table 3.

Table 3. Result of Protein Yoghurt During Storage

\begin{tabular}{lccc} 
& Milk Treatment Factor & 0 & 4 \\
\multicolumn{1}{c}{ Treatment Factor of Starter Type (E) } & $(\mathrm{S})$ & week & weeks \\
\hline $\mathrm{e}_{1}$ (Combination L. bulgaricus and $S$. & $\mathrm{s}_{1}$ (fresh milk) & $3.05 \mathrm{a}$ & $3.01 \mathrm{~b}$ \\
thermophillus & $\mathrm{s}_{2}$ (skim milk) & $1.49 \mathrm{e}$ & $1.47 \mathrm{f}$ \\
$\mathrm{e}_{2}$ (Combination L. bulgaricus, S. thermophillus, & $\mathrm{s}_{1}$ (fresh milk) & $2.68 \mathrm{c}$ & $2.66 \mathrm{~d}$ \\
B. longum and L. casei) & $\mathrm{s}_{2}$ (skim milk) & $1.16 \mathrm{~h}$ & $1.39 \mathrm{~g}$ \\
\hline The numbers followed by the same letters in the same column are not significantly different in Duncan's \\
multiple range test $\alpha=0.05$
\end{tabular}

The results of the statistical analysis showed that the types of milk and combine of starter significantly affected the yoghurt protein levels. Table 3 was showed that protein content of each treatment decreased except in the combination of 4 starters in skim milk which initially $1.16 \%$ increased to $1.39 \%$. The highest protein content at the 4 week of storage was obtained from the treatment using a combination of 2 starters in fresh milk by $3.01 \%$ from the results obtained from fresh milk samples with a treatment of 2 starter combinations. The results of this study are included in the Indonesian National Standard (SNI) 2981: 2009 for the quality of yoghurt with minimum protein requirement of 2.7\%.

Yoghurt protein content was determined by the quality of fresh milk as the important material of manufacture. The quality of milk protein depend on nutrition maintenance of the cattle. Also the high content of protein of the cow milk resulting the better quality of the yoghurt production $(25,48,49)$. According to Farida (2008) and Abe et al. (2009b) suggested that more microbes contained in yoghurt, the higher protein content because most of the constituent components of microbes are proteins $(50,51)$. However, in terms of fermentation, the best fermenting milk come from bacteria L. bulgaricus and S. thermophillus. Castro et al. (1997); Dilli et al. (2010); Yilmaz-Ersan and Kurdal (2014) reported that beside as fermentation bacteria, L. bulgaricus and S. thermophillus has ability against pathogen and very susceptible in freeze condition (52-54). The finding showed the best result of the average protein produced in the addition of both L. bulgaricus and $S$. thermophillus is higher than the combination of L. bulgaricus, S. thermophillus, B. longum and L. casei. Abe et al. (2009a) reported that Bifidobacterium effective used as single starter in the powder form (55).

Decreased protein content due to lactic acid fermentation caused by microorganisms that active in fermentation. They are showed the differences in protein content that is the basic ingredient, types of starter used and the process of making them, especially the level of thickening of milk causing differences in the quality of yoghurt $(46,56)$. Based on the research results of Hafsah and Astrina (2012), the average protein content with the addition of S. thermophillus starter was $2.87 \%$, the addition of L. bulgaricus starter was $0.0017 \%$ and the addition of combination starter was $2.18 \%$. The low level of protein compared to SNI BBPOM is suspected because the milk used in making yoghurt also contain low protein which is $2.48 \%$ and because of the susceptibility factor for a rather long sampling time before the starter process is made up to the stage of fermentation of cow's milk into yoghurt. 
3.4. Lactose levels

Lactose is one component of milk that will be fermented by BAL in the process of making yoghurt (Rukmana, 2001 and Legowo, 2002). Lactose levels yoghurt from fresh milk and skim milk with a combination of several starters was presented in Table 4.

\begin{tabular}{|c|c|c|c|}
\hline Treatment Factor of Starter Type (E) & $\begin{array}{l}\text { Milk Treatment } \\
\text { Factor (S) }\end{array}$ & $\begin{array}{l}0 \\
\text { week (\%) }\end{array}$ & $\begin{array}{l}4 \\
\text { weeks (\%) }\end{array}$ \\
\hline e1 (Combination L. bulgaricus and S. & s1 (fresh milk) & $3.47 \mathrm{a}$ & $3.09 \mathrm{~d}$ \\
\hline thermophillus & s2 (skim milk) & $2.47 \mathrm{f}$ & $2.33 \mathrm{~g}$ \\
\hline e2 (Combination L. bulgaricus, S. thermophillus, & s1 (fresh milk) & $3.28 \mathrm{~b}$ & $3.11 \mathrm{c}$ \\
\hline B. longum dan L. casei) & s2 (skim milk) & $2.58 \mathrm{e}$ & $2.48 \mathrm{f}$ \\
\hline
\end{tabular}

The numbers followed by the same letters in the same column are not significantly different in Duncan's multiple range test $\alpha=0.05$

Data analysis in Table 4 was showed there a significant influence on the type of milk and starter used on lactose content in the yoghurt produced. Lactose levels in each treatment decreased at 4 weeks. The lactose level of fresh milk with combination of 2 starters at 0 weeks, in the beginning $3.47 \%$ decreased to $3.09 \%$, yoghurt from skim milk with a combination of 2 starters $2.47 \%$ decreased to $2.33 \%$ at 4 weeks; fresh milk yoghurt with a combination of 4 starters has number $3.28 \%$ decreased $3.11 \%$ and skim milk yoghurt with 4 combinations of $2.58 \%$ decreased $2.48 \%$. Decreased levels of lactose yoghurt due to the activity of Lactic Acid Bacteria (BAL) impact the number of lactose to lactic acid during fermentation (57). The existence of BAL activity in the combination of 2 starters and 4 starter combinations in research caused the lactose in yoghurt will decrease and increasing lactic acid levels. Rahayu (1998) suggested that LAB affected the lactose contain in milk to lactic acid (58). During the fermentation process, lactose from milk was converted to lactic acid approximately $30 \%$ while the rest is still in the form of lactose. Gilliland et al. (2002) and Hsiao et al., (2004) reported that viability of L. bulgaricus will decrease in long day storage and maintenance of packaging $(10,59)$.

According to Liu and Tsao (2009) and Octaviana et al. (2015) reported that the level of starter concentration used in this study both in the combination of 2 starters and 4 starters will also affect the rate of lactose breakdown at the same incubation time and temperature $(60,61)$. An increase in starter concentration will be followed by increased activity and breeding. With a range of lactose content $2.33-3.11 \%$ for 4 weeks of storage in a combination of 2 starters and 4 starters in fresh milk and skim milk showed that the lactose levels are still in normal levels, where the standard lactose levels generally range $<4.6 \%$

\section{Conclusion}

There is a significant influence between the types of milk base ingredients (fresh milk and skim milk) and the number of starters (2 starters i.e : L. bulgaricus and S. thermophillus; and 4 starters such as : L. bulgaricus, S. thermophillus, B. longum and L. casei ) used on fat, protein and lactose content of yoghurt not significant effect on the $\mathrm{pH}$ value produced during 4 weeks of storage.

A good $\mathrm{pH}$ value was obtained from fresh milk ingredients with a combination of 4 starters, a good level of yoghurt protein was produced on fresh milk ingredients with a 
combination of 2 starters, good fat content was obtained from skim milk ingredients with a combination of 2 starters and fresh milk with a combination of 4 starters, while good lactose content is in a combination of 2 starters both in fresh milk and in skim milk. From the measurement results of $\mathrm{pH}$, fat, protein and lactose parameters are still in accordance with the standards of cow's milk yoghurt.

Cow's milk and skim milk can be used as ingredients for yoghurt with the notes skim milk is still lower in physicochemical properties compared to fresh cow's milk.

\section{References}

1. Widodo W. Bioteknologi fermentasi susu. Pus Pengemb Bioteknol Univ Muhammadiyah Malang, Malang. 2002;

2. Fagnani R, Schuck J, Botaro BG, Santos FC dos. Extended storage of cold raw milk on yogurt manufacturing. Pesqui Agropecuária Bras. 2017;52(2):104-12.

3. Rachman A, Taufik E, Arief II. Karakteristik Yoghurt Probiotik Rosella Berbahan Baku Susu Kambing dan Susu Sapi Selama Penyimpanan Suhu Ruang. J Ilmu Produksi dan Teknol Has Peternak. 2018;6(2):73-80.

4. Maheswari R, Ronny RN. Perbandingan Kandungan Nutrisi ASI, Susu sapi, dan Susu kambing. Teknol Has Ternak Bogor Fak Peternak IPB. 2008;

5. Resnawati H. Kualitas susu pada berbagai pengolahan dan penyimpanan. JITV. 2014;19(2).

6. Masco L, Huys G, De Brandt E, Temmerman R, Swings J. Culture-dependent and cultureindependent qualitative analysis of probiotic products claimed to contain bifidobacteria. Int J Food Microbiol. 2005;102(2):221-30.

7. Suriasih K, Hartawan M, Sucipta N, Lindawati SA, Okarini IA. Microbiological, chemical and sensory characteristics of yoghurt prepared from blended cow and goat milk. Food Sci Qual Manag. 2014;34:557-2225.

8. Syainah E, Novita S. Kajian pembuatan yoghurt dari berbagai jenis susu dan inkubasi yang berbeda terhadap mutu dan daya terima. J Skala Kesehat. 2014;5(1).

9. Abubakar, Budi A, Harsono H. Pengaruh Suhu dan Macam Susu Terhadap Mutu Yoghurt Selama Penyimpanan. In: Seminar Nasional Peternakan dan Veteriner. Bogor: Pusat Penelitian dan Pengembangan Peternakan. Badan Penelitian dan Pengembangan Pertanian; 2000. p. 755-760.

10. Hsiao H, Lian W, Chou C. Effect of packaging conditions and temperature on viability of microencapsulated bifidobacteria during storage. J Sci Food Agric. 2004;84(2):134-9.

11. Oliveira MN, Sodini I, Remeuf R, Tissier JP, Corrieu G. Manufacture of fermented lactic beverages containing probiotic cultures. J Food Sci. 2002;67(6):2336-41.

12. Sumantri I. Pemanfaatan Mangga Lewat Masak Menjadi Fruitghurt dengan Mikroorganisma Lactobacillus bulgaricus. In: Prosiding Seminar Nasional Rekayasa Kimia dan Proses Jurusan Teknik Kimia Fakultas Teknik UNDIP. 2004.

13. Ismai MM. Chemical and microbial characterizations of bio-yoghurt made using $A B T$ culture, cow milk and coconut milk. EC Microbiol. 2017;5:109-24.

14. Boylston TD, Vinderola CG, Ghoddusi HB, Reinheimer JA. Incorporation of bifidobacteria into cheeses: challenges and rewards. Int Dairy J. 2004;14(5):375-87.

15. Phillips $M$, Kailasapathy $K$, Tran L. Viability of commercial probiotic cultures (L. acidophilus, Bifidobacterium sp., L. casei, L. paracasei and L. rhamnosus) in cheddar 
cheese. Int J Food Microbiol. 2006;108(2):276-80.

16. Sabikhi L, Kumar MHS, Mathur BN. Bifidobacterium bifidum in probiotic Edam cheese: influence on cheese ripening. J Food Sci Technol. 2014;51(12):3902-9.

17. Dimitrellou D, Salamoura C, Kontogianni A, Katsipi D, Kandylis P, Zakynthinos G, et al. Effect of Milk Type on the Microbiological, Physicochemical and Sensory Characteristics of Probiotic Fermented Milk. Microorganisms. 2019;7(9):274.

18. Glušac J, Stijepić M, Đurđević-Milošević D, Milanović $S$, Kanurić K, Vukić V. Growth and viability of Lactobacillus delbrueckii subsp. bulgaricus and Streptococcus thermophilus in traditional yoghurt enriched by honey and whey protein concentrate. Iran J Vet Res. 2015;16(3):249.

19. Andriani M dan Khasanah LU. Kajian Karakteristik Fisiko Kimia dan Sensori Yogurt dengan Penambahan Ekstrak Ubi Jalar (Ipomoea batatas L.). UNS (Sebelas Maret University); 2010.

20. Mega O, Jahidin JP, binti Sulaiman N, Yusuf M, Arifin M, Arief II. Total Count of Lactic Acid Bacteria in Goats and Cows Milk Yoghurt using Starter S. thermophilus RRAM-01, L. bulgaricus RRAM-01 and L. acidophilus IIA-2B4. Bul Peternak. 44(1).

21. Rahmawati IS, Suntornsuk W. Effects of fermentation and storage on bioactive activities in milks and yoghurts. Procedia Chem. 2016;18:53-62.

22. Abdel Moneim ES, Rania MA, Zakaria AS. Effects of Storage on Quality of Yoghurt Prepared from Cows' and Goat's Milk and Pure Strains of Lactic Acid Bacteria. J Sci Tech. 2011;12(1):136-43.

23. Lourens-Hattingh A, Viljoen BC. Yogurt as probiotic carrier food. Int dairy J. 2001;11(12):1-17.

24. Wulansari PD, Kusmayadi A. Chemical Properties and Characteristics of Cow Milk Yogurt with Different Additional Fruit and Storage Time. Anim Prod. 2016;18(2):113-7.

25. Sodini I, Lucas A, Oliveira MN, Remeuf F, Corrieu G. Effect of milk base and starter culture on acidification, texture, and probiotic cell counts in fermented milk processing. J Dairy Sci. 2002;85(10):2479-88.

26. Saarela $\mathrm{MH}$, Alakomi $\mathrm{H}$, Puhakka A, Mättö J. Effect of the fermentation $\mathrm{pH}$ on the storage stability of Lactobacillus rhamnosus preparations and suitability of in vitro analyses of cell physiological functions to predict it. J Appl Microbiol. 2009;106(4):1204-12.

27. Saccaro DM, Tamime AY, Pilleggi ALOPS, Oliveira MN. The viability of three probiotic organisms grown with yoghurt starter cultures during storage for 21 days at $4 \mathrm{C}$. Int J Dairy Technol. 2009;62(3):397-404.

28. Özer BH, Kirmaci HA. Functional milks and dairy beverages. Int J Dairy Technol. 2010;63(1):1-15.

29. Yerlikaya O. Starter cultures used in probiotic dairy product preparation and popular probiotic dairy drinks. Food Sci Technol. 2014;34(2):221-9.

30. Helferich W, Dennis C. WESTHOFF. 1980. All about yoghurt. Prentice-Hall Inc. Englewood Cliffs, New Jersey;

31. Morelli L. Yogurt, living cultures, and gut health. Am J Clin Nutr. 2014;99(5):1248S1250 S.

32. El Bashiti TAI. Production of Yogurt by locally isolated starters: Streptococcus thermophilus and Lactobacillus bulgaricus. Al Azhar Univ. 2010;12:56-8.

33. Rahman SR, Mukta MZAS. Studies On Yogurt Production Using Lactobacillus bulgaricus 
AND Streptococcus thermophilus Isolated From Market Yogurt.

34. Fatmawati U, Prasetyo FI, TA MS, Utami AN. Karakteristik yogurt yang terbuat dari berbagai jenis susu dengan penambahan kultur campuran Lactobacillus bulgaricus dan Streptococcus thermophillus. Bioedukasi J Pendidik Biol. 2013;6(2):1-9.

35. Buckle KA, Edwards RA, Fleet GH, Wootton M, Purnomo H. Ilmu pangan. Jakarta, Indonesia: UI Press; 2019.

36. Stanley JK. Determining the Bacterial Content of Milk [Internet]. 2008 [cited 2018 Sep 20]. Available from: https://scienceproject.com

37. Khusmiati, T., Sumidjah dan Handayani R. Pengaruh Penambahan Teh Hijau Terhadap Sifat Fisik dan Kimiawi Yoghurt. In: Seminar Nasional Teknologi Peternakan dan Veteriner. Bogor: Pusat Penelitian dan Pengembangan Peternakan. Badan Penelitian dan Pengembangan Pertanian; 2004. p. 262-7.

38. Kim S, Lim C-H, Lee C, An G. Optimization of growth and storage conditions for lactic acid bacteria in yogurt and frozen yogurt. J Korean Soc Appl Biol Chem. 2009;52(1):76-9.

39. Jay JM, Loessner MJ, Golden DA. Modern food microbiology. Springer Science \& Business Media; 2008.

40. Lahtinen SJ, Gueimonde M, Ouwehand AC, Reinikainen JP, Salminen SJ. Probiotic bacteria may become dormant during storage. Appl Environ Microbiol. 2005;71(3):1662-3.

41. Oktavia HM, Kusumawati N, Kuswardhani I. Effect of storage time during distribution and marketing on the viability of lactic acid bacteria and acidity levels in black mulberry yogurt (Morus nigra L.). J Teknol Pangan dan Gizi. 2015;14(1):22-30.

42. Seveline. Pengembangan Produk Probiotik dari Isolat Klinis Bakteri Asam Laktat Dengan Menggunakan Teknik Pengeringan Semprot dan Pengeringan Beku. Institut Pertanian Bogor; 2005.

43. Shah N, Jelen P. Survival of lactic acid bacteria and their lactases under acidic conditions. J Food Sci. 1990;55(2):506-9.

44. Sunarlim R, Setiyanto H. Penggunaan Berbagai Tingkat Kadar Lemak Susu Kambing dan Susu Sapi Terhadap Mutu dan Cita Rasa Yoghurt. In: Prosiding Seminar Nasional Teknologi Peternakan dan Veteriner Puslitbangnak, Bogor. 2001.

45. Yusmarini AM, Hadiwiyoto S. Perubahan Oligosakarida pada Susu Kedelai dalam Proses Pembuatan Yoghurt. Berk Penelit Pasca Sarjana(BPPS) Yogyakarta Univ Gadjah Mada. 1997;

46. Hafsah A. Pengaruh variasi starter terhadap kualitas yoghurt susu sapi. J Bionature. 2012;13(2):96-102.

47. Fadro RE, Restuhadi F. Pengaruh Penambahan Susu Skim dalam Pembuatan Minuman Probiotik Susu Jagung (Zea mays L.) Menggunakan Kultur Lactobacillus acidophilus'. Teknol Has Pertanian, Fak Pertanian, Riau, Pekan Baru. 2015;14(2):28-36.

48. Gueimonde M, Delgado S, Mayo B, Ruas-Madiedo P, Margolles A, de los Reyes-Gavilán CG. Viability and diversity of probiotic Lactobacillus and Bifidobacterium populations included in commercial fermented milks. Food Res Int. 2004;37(9):839-50.

49. Jiménez AM, Murcia MA, Parras $P$, Martínez-Tomé $M$. On the importance of adequately choosing the ingredients of yoghurt and enriched milk for their antioxidant activity. Int J food Sci Technol. 2008;43(8):1464-73.

50. Farida H. Pengaruh Perbedaan Konsentrasi Starter dan Sukrosa Terhadap Kualitas Bulgaricus Milk. Skripsi S1 Fakultas Peternakan UGM. Yogyakarta; 2008. 
51. Abe F, Tomita S, Yaeshima T, Iwatsuki K. Effect of production conditions on the stability of a human bifidobacterial species Bifidobacterium longum in yogurt. Lett Appl Microbiol. 2009;49(6):715-20.

52. Yilmaz-Ersan L, Kurdal E. The production of set-type-bio-yoghurt with commercial probiotic culture. Int J Chem Eng Appl. 2014;5(5):402.

53. Castro HP, Teixeira PM, Kirby R. Evidence of membrane damage in Lactobacillus bulgaricus following freeze drying. J Appl Microbiol. 1997;82(1):87-94.

54. Dilli ZH, De N, Sudi IY, Ali-Dunkrah U. A study on inhibitory effects of Lactobacillus bulgaricus and Streptococcus thermophilus as probiotics on some clinical pathogens. Researcher. 2010;11:38-41.

55. Abe F, Miyauchi H, Uchijima A, Yaeshima T, Iwatsuki K. Effects of storage temperature and water activity on the survival of bifidobacteria in powder form. Int J Dairy Technol. 2009;62(2):234-9.

56. Sellars RL. Fermented dairy foods. J Dairy Sci. 1981;64(6):1070-6.

57. Legowo DLRAM, Dwiloka B. Total Bakteri Asam Laktat, Ph, Dan Kadar Laktosa Yoghurt Dengan Penambahan Tepung Jewawut. Agromedia. 2015;33(2).

58. Rahayu WP. Penuntun Praktikum Organoleptik. Jur Teknol Pangan, Fak Teknol Pertan Inst Pertan Bogor, Bogor. 1998;

59. Gilliland SE, Reilly SS, Kim GB, Kim HS. Viability during storage of selected probiotic lactobacilli and bifidobacteria in a yogurt-like product. J Food Sci. 2002;67(8):3091-5.

60. Liu S-Q, Tsao M. Enhancement of survival of probiotic and non-probiotic lactic acid bacteria by yeasts in fermented milk under non-refrigerated conditions. Int J Food Microbiol. 2009;135(1):34-8.

61. Oktaviana AY, Suherman D, Sulistyowati E. Pengaruh Ragi Tape terhadap pH, Bakteri Asam Laktat dan Laktosa Yogurt. J Sain Peternak Indones. 2015;10(1):22-31. 